\title{
sciendo
}

RESEARCH PAPERS FACULTY OF MATERIALS

SCIENCE AND TECHNOLOGY IN TRNAVA

SLOVAK UNIVERSITY OF TECHNOLOGY

IN BRATISLAVA

2018, Volume 26, Number 43

DOI 10.2478/rput-2018-0029

\section{MICROSTRUCTURE CHARACTERISTICS OF BORATED AUSTENITIC STAINLESS STEEL WELDS}

\author{
Mária DOMÁNKOVÁ ${ }^{1}$, Marek ADAMECH ${ }^{2}$, Jana PETZOVÁ², \\ Katarína BÁRTOVÁ ${ }^{1}$, Peter PINKE ${ }^{3}$ \\ ${ }^{1}$ SLOVAK UNIVERSITY OF TECHNOLOGY IN BRATISLAVA, \\ FACULTY OF MATERIALS SCIENCE AND TECHNOLOGY IN TRNAVA, \\ INSTITUTE OF MATERIALS SCIENCE, \\ ULICA JÁNA BotTU 2781/25, 91724 TRNAVA, SLOVAK REPUBLIC \\ e-mail: maria.domankova@stuba.sk, katarina.bartova@stuba.sk \\ ${ }^{2}$ VUJE A.S., OKRUŽNÁ 5, 91845 TRNAVA, SLOVAK REPUBLIC \\ e-mail: Marek.Adamech@vuje.sk, Jana.Petzova@vuje.sk \\ ${ }^{3}$ ÓBUDA UNIVERSITY, \\ DONÁT BÁNKI FACULTY OF MECHANICAL AND SAFETY ENGINEERING, \\ INSTITUTE OF MATERIALS AND MANUFACTURING SCIENCES \\ 1081 BUDAPEST, NÉPSZÍNHÁZ UTCA 8., HUNGARY \\ e-mail: pinke.peter@bgk.uni-obuda.hu \\ Received: 19.11.2018, Accepted: 19.12.2018, Published: 29.01.2019
}

\begin{abstract}
Borated austenitic stainless steel is used in nuclear industry due to the high neutron absorption efficiency. The plasma, laser and electron beam welding experiments were used for the study of the weld joints microstructure. The microstructure changes caused by welding process were observed by light optical microscopy and transmission electron microscopy. The microstructural characterization and microchemical analysis showed significant changes of the phase composition in the weld metal mainly. The austenitic dendrites were surrounded by eutectics, which were the mixture of the $M_{2}(C, B)$ and $M_{23}(C, B)$ borocarbides, $\delta$-ferrite and austenite.
\end{abstract}

\section{Key words}

Borated austenitic stainless steel, welding, microstructure, transmission electron microscopy

\section{INTRODUCTION}

Austenitic stainless steels exhibit a stable or metastable face-centred cubic crystal structure at room temperature and are the most favoured construction materials for various components required in the chemical, petrochemical and nuclear industries (1-3). Boron containing austenitic stainless steels known as borated austenitic stainless steels (BASS) has been widely 
used in the nuclear industry as reactor control materials in the nuclear reactor due to their ability to absorb thermal neutrons (4-6).

Increased thermal neutron absorption cross-section of boron (B) leads to a wide-spread use of B-containing materials, such as thermal-reactor control rods and burnable poisons in nuclear power plants (4-6). BASS contain boron either alloyed or dispersed in the austenitic matrix. According to their chemical composition and mechanical properties and based on ASTM specification A887, BASS are classified to eight boron levels and two grades per type (4). Typical boron content varies from 0.2 to $2.5 \mathrm{wt}$. \%

The limited solubility of boron in austenitic matrix caused the formation of the intermetallic compounds rich in $\mathrm{Fe}, \mathrm{Cr}$ and $\mathrm{Ni}$. The formation of intermetallic compounds in BASS is due to a reduction in ductility and the formation of iron-boron eutectic phase. The heat of welding can result in formation of low melting eutectic phase leading to liquation cracking in the heat affected zone (HAZ) $(4,5)$. The hot cracking tendency was found to be more pronounced with boron content less than $0.5 \mathrm{wt}$. $\%$.

There are only a few literature sources dealing with BASS and their weldability. In this research article, we report the effect of laser welding, electron beam welding and plasma welding processes on the microstructure of the weld joints. The resultant welds were characterised using metallography and microstructural analysis by light optical microscopy and transmission electron microscopy, respectively. The analysis was supplemented by the selected area electron diffraction for the phase identification and energy-dispersive X-ray spectrometry, which was used for the microchemical analyses of the secondary phases.

\section{EXPERIMENTAL PROCEDURE}

Three experimental steels of the chemical composition as shown in Table 1 were welded by three different weld technologies.

\begin{tabular}{|c|c|c|c|c|c|c|c|c|c|c|c|}
\hline Table 1: Chemical composition of the experimental steels \\
\hline Sample & $\begin{array}{c}\text { Weld } \\
\text { technology }\end{array}$ & $\mathbf{C}$ & $\mathbf{M n}$ & $\mathbf{S i}$ & $\mathbf{P}$ & $\mathbf{S}$ & $\mathbf{C r}$ & $\mathbf{N i}$ & $\mathbf{B}$ & $\mathbf{N}$ & Co \\
\hline & $\begin{array}{c}\text { plasma } \\
\text { welding }\end{array}$ & 0.020 & 0.92 & 0.35 & 0.016 & 0.003 & 19.38 & 13.31 & 1.13 & 0.025 & 0.19 \\
\hline 1d & laser welding & 0.020 & 1.49 & 0.83 & 0.025 & 0.007 & 19.49 & 12.52 & 1.11 & 0.013 & 0.070 \\
\hline 2d & $\begin{array}{c}\text { electron beam } \\
\text { welding }\end{array}$ & 0.025 & 1.57 & 0.55 & 0.026 & 0.001 & 18.40 & 12.20 & 1.24 & 0.022 & - \\
\hline
\end{tabular}

The plasma welding process was conducted according to the manufacturing-inspection plan of ŠKODA JS a.s. The laser welding experiments were performed using 5kW IPG YLS5000 fibre laser with $100 \mu \mathrm{m}$ optical fibre and $250 \mathrm{~mm}$ focal length. For the keyhole welds, laser power in the range of $1.7-4 \mathrm{~kW}$ was used. The electron beam welding experiments used voltage $\mathrm{U}_{\mathrm{z}}=33 \mathrm{kV}$; current $\mathrm{I}_{\mathrm{z}}=52 \mathrm{~mA}$; welding rate $\mathrm{v}=50 \mathrm{~mm} / \mathrm{s}$.

The samples for light optical microscopy (LOM) examination were polished up to fine diamond $(\sim 3 \mu \mathrm{m})$ finish. The specimens were etched chemically for $60 \mathrm{~s}$. using a solution of $10 \mathrm{ml} \mathrm{H}_{2} \mathrm{SO}_{4}+10 \mathrm{ml} \mathrm{HNO}_{3}+20 \mathrm{ml} \mathrm{HF}+50 \mathrm{ml}$ distilled $\mathrm{H}_{2} \mathrm{O}$. Then the screening of microstructures was done using NEOPHOT 32 light microscope equipped with the CCD camera (7).

For the individual secondary phases identification, transmission electron microscopy (TEM) of the dual stage replicas was utilised. Thin foils suitable for TEM observation were prepared from each of the samples. Small discs of $3 \mathrm{~mm}$ in diameter and about $0.1 \mathrm{~mm}$ thick were jet-electropolished in electrolyte $\mathrm{HNO}_{3}: \mathrm{CH}_{3} \mathrm{OH}=3: 7$, at $-10^{\circ} \mathrm{C}$ and $15 \mathrm{~V}$ to obtain transparent areas near the central hole. The jet-electropolishing was done by TenuPol 5. TEM 
observations were performed using JEOL $200 \mathrm{CX}$ operating at $200 \mathrm{kV}$ and Philips CM 300 operating at $300 \mathrm{kV}$ equipped with energy-dispersive X-ray spectrometer (EDX), which was used for the microchemical analysis. The analysis was supplemented by selected area electron diffraction (SAED) for the phase identification (7).

\section{RESULTS AND DISCUSSION}

Light optical microscopy (LOM) Cross section macrographs of the laser beam weld joint is presented in Fig.1. The microstructure of the welding joint characteristic regions of the sample $1 \mathrm{~d}$ is documented by Fig.2. The microstructure of weld metal (WM) exhibited a solidification structure (Fig.2a). The austenite dendrites (light) were surrounded by a matrix of iron-chromium-boron eutectic (dark). The ratio between dendrites and eutectic regions was identical. Fig.2b shows the microstructure of the heat affected zone (HAZ). The microstructure consists of the discontinuous precipitate regions and austenitic polyhedral grains. The discontinuous precipitate regions are the results of the dissolution of the big boride particles in the base metal (BM) during heating-up of the weld process and follow-up precipitation of secondary phases during cooling. The microstructure of BM consists of polyhedral austenitic grains with twinning typical for FCC microstructure and the big particles of boride $\left(\mathrm{M}_{2} \mathrm{~B}\right) . \mathrm{M}$ indicates that both $\mathrm{Fe}$ and $\mathrm{Cr}$ are present in the boride and borocarbide phases, respectively. Very similar microstructures of the weld joints of the samples 2d (Fig.3) and 3d (Fig.4) were observed by LOM. The found differences were in the ratio between the dendrites and eutectics regions and the width of HAZ, too. The content of dendrites was around $60 \%$ and $40 \%$ of eutectics in the case of the sample $2 \mathrm{~d}$. The content of dendrites was around $30 \%$ and $70 \%$ of eutectics in the case of the sample $3 \mathrm{~d}$.

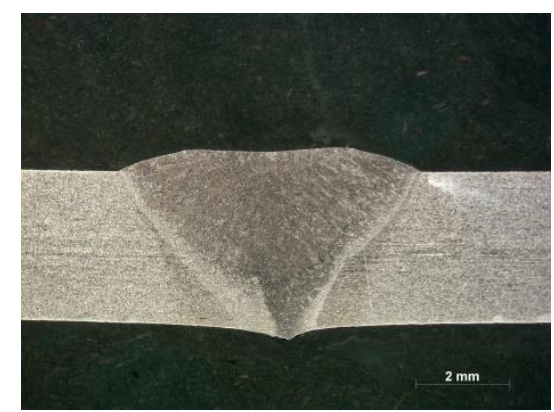

Fig.1 Cross-section of laser beam weld joint (sample 2d)
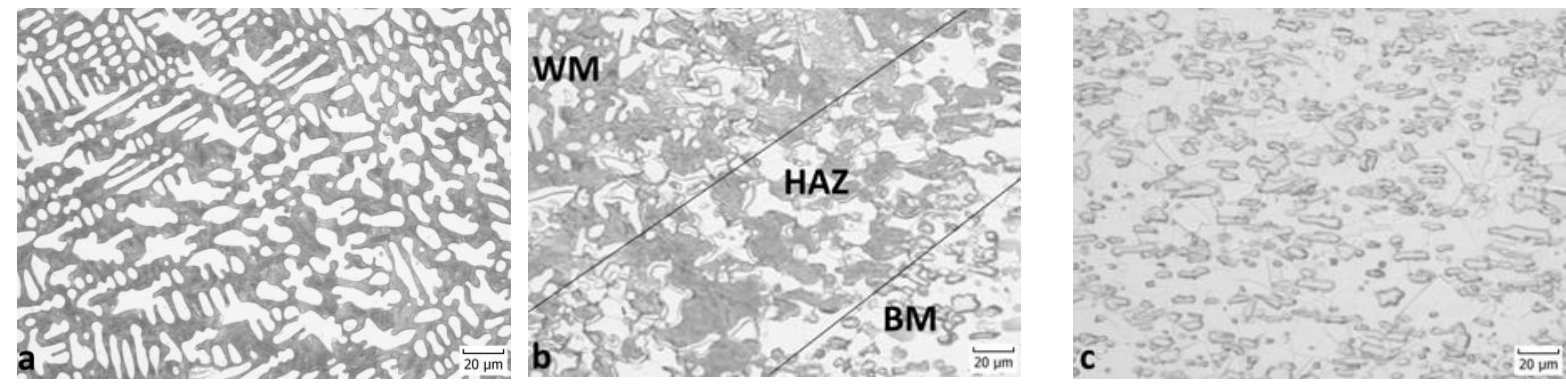

Fig. 2 Microstructure of the weld joint of sample 1d: a) weld metal (WM), b) heat affected zone $(H A Z), c)$ base metal (BM) - observed by LOM 

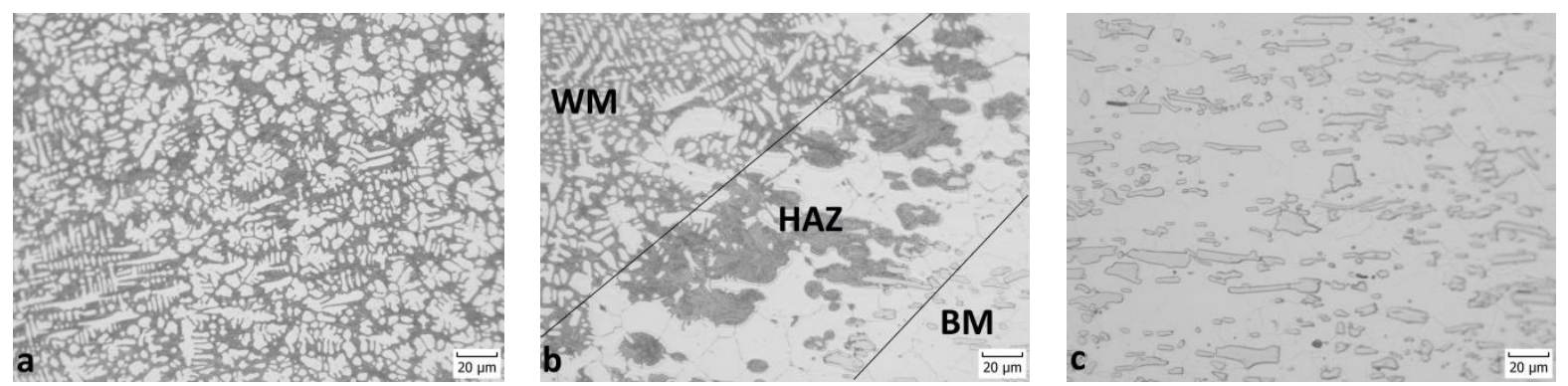

Fig. 3 Microstructure of the weld joint of sample 2d: a) weld metal (WM), b) heat affected zone (HAZ), c) base metal (BM) - observed by LOM
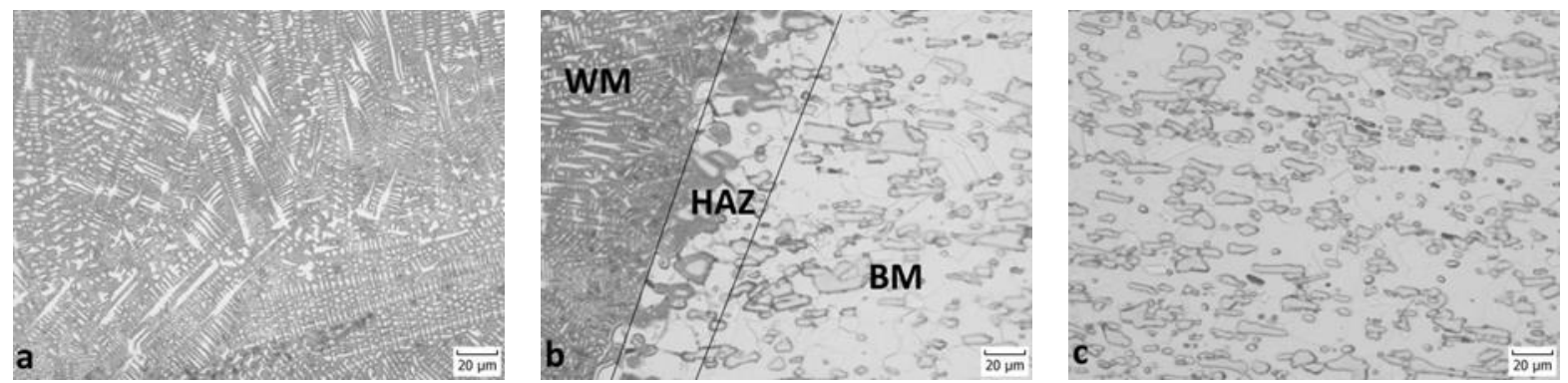

Fig. 4 Microstructure of the weld joint of sample $3 d$ : a) weld metal (WM), b) heat affected zone (HAZ), c) base metal (BM)-observed by LOM

Transmission electron microscopy (TEM) According to the results of LOM where secondary phases in the characteristic regions of the weld joints were supposed, TEM investigation was applied to identify the secondary phases. Figs. 5 and 6 show the microstructure of WM observed by TEM using extraction replicas, while Figs.7 and 8 show the character of the microstructure observed by the thin foils. The mixture of the phases in the eutectic regions was confirmed by TEM. The eutectic regions exhibited lamellar (Fig.5) or labyrinth (Fig.6) morphology. The $\mathrm{M}_{2}(\mathrm{C}, \mathrm{B})$ and $\mathrm{M}_{23}(\mathrm{C}, \mathrm{B})_{6}$ borocarbides, $\delta$-ferite and austenite were confirmed by electron diffraction (Fig.9 and Table 2, Fig.10 and Table 3) inside the eutectic regions.

The microstructure of HAZ is documented by Figs.11 and 12. TEM observation confirms the supposition that heating-up causes dissolution of the big boride particles, and subsequently the discontinuous precipitation of secondary phases occurred during cooling of the weld joint. The lamellar structure was observed near to the partially dissolved big boride particles (Fig.11). The precipitation of secondary phases at the austenitic grain boundaries was observed in HAZ, too (Fig.12).

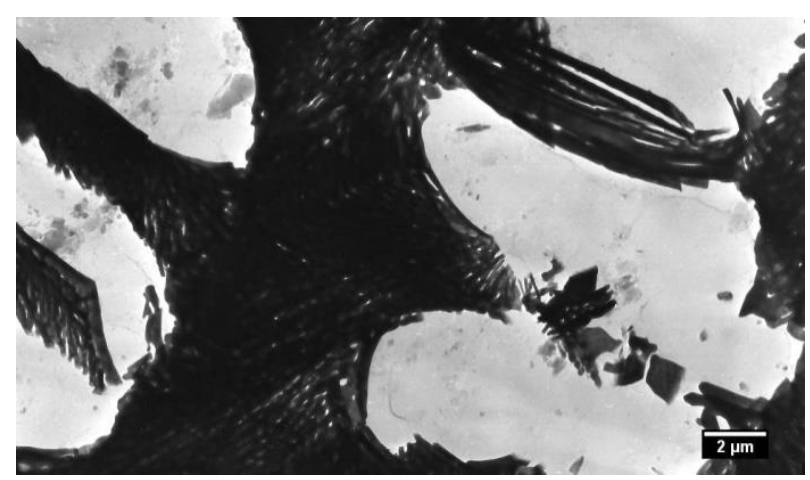

Fig. 5 A detail of the eutectics regions in WM secondary phases of different morphology were observed (TEM-replica)

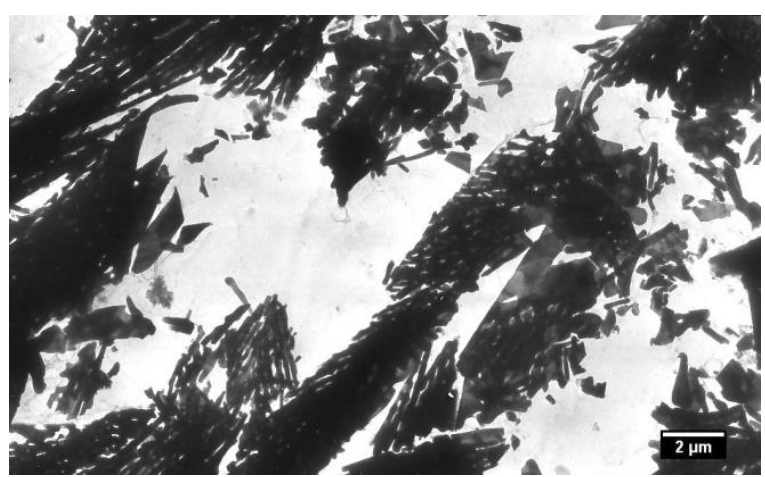

Fig. 6 A detail of the eutectics regions in WMsecondary phases of different morphology were observed (TEM-replica) 


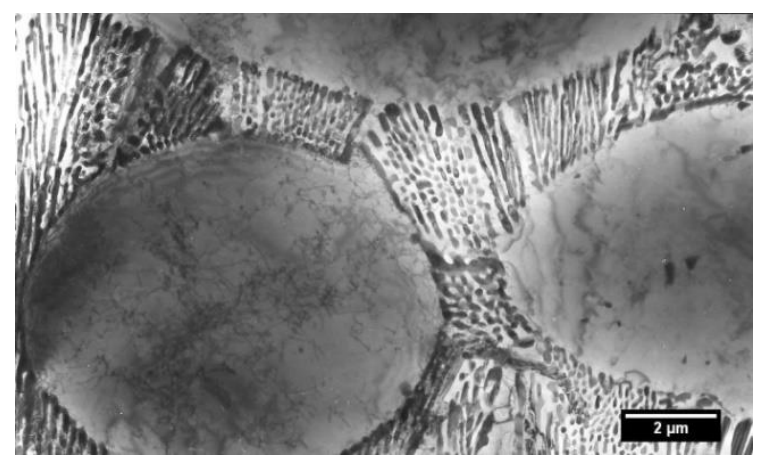

Fig. 7 Microstructure of WM (TEM-thin foil)

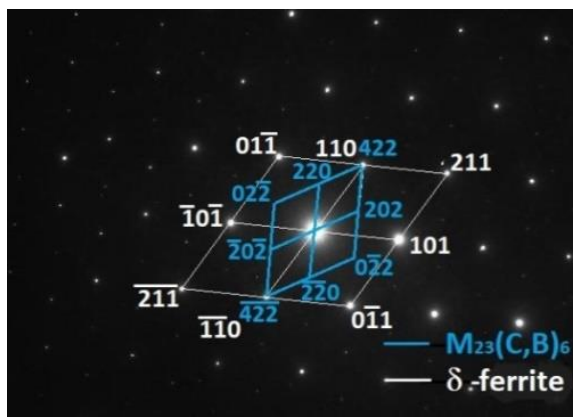

Fig. 9 An electron diffraction pattern from eutectic region. Indexing of diffraction patterns follows from Table 2

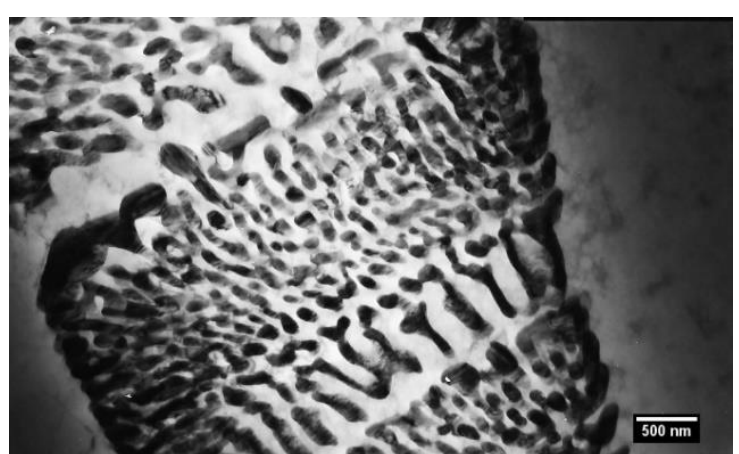

Fig. 8 A detail of the eutectics region in $W M-$ secondary phases with different morphology were observed (TEM-thin foil)

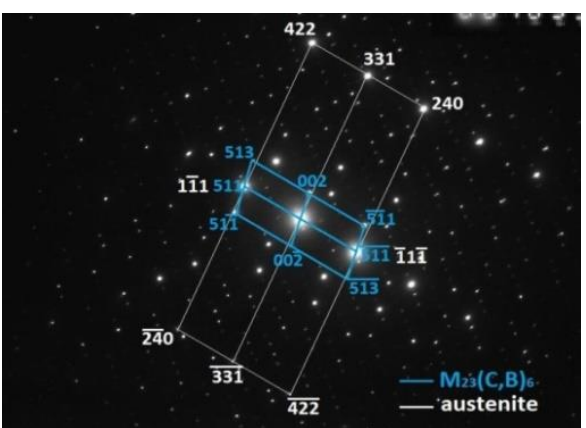

Fig. 10 An electron diffraction pattern from eutectic region. Indexing of diffraction patterns follows from Table 3

Table 2: Solution of diffraction patterns of the $\delta$-ferrite and secondary phase (Fig. 9)

\begin{tabular}{|c|c|c|c|c|c|c|c|}
\hline \multicolumn{4}{|c|}{ White motive } & \multicolumn{4}{c|}{ Blue motive } \\
\hline \multicolumn{2}{|c|}{ Diffraction pattern } & \multicolumn{2}{|c|}{$\begin{array}{c}\text { Table values of } \\
\delta \text {-ferrite }\end{array}$} & \multicolumn{2}{c|}{ Diffraction pattern } & \multicolumn{2}{c|}{$\begin{array}{c}\text { Table values of } \\
\mathbf{M}_{23}(\mathbf{C , B})_{\mathbf{6}} \text { borocarbide }\end{array}$} \\
\hline No. & $\begin{array}{c}\mathrm{d}_{\mathrm{hkl}} \\
\left(\cdot 10^{-10} \mathrm{~m}\right)\end{array}$ & $\begin{array}{c}\mathrm{d}_{\mathrm{hkl}} \\
\left(\cdot 10^{-10} \mathrm{~m}\right)\end{array}$ & $(\mathrm{h} \mathrm{k} 1)$ & No. & $\begin{array}{c}\mathrm{d}_{\mathrm{hkl}} \\
\left(\cdot 10^{-10} \mathrm{~m}\right)\end{array}$ & $\begin{array}{c}\mathrm{d}_{\mathrm{hkl}} \\
\left(\cdot 10^{-10} \mathrm{~m}\right)\end{array}$ & $(\mathrm{h} \mathrm{k} 1)$ \\
\hline 1 & 2.13 & 2.09 & $(110)$ & 1 & 3.81 & 3.77 & $(220)$ \\
\hline 2 & 2.13 & 2.09 & $(101)$ & 2 & 3.81 & 3.77 & $(202)$ \\
\hline 3 & 1.25 & 1.20 & $(211)$ & 3 & 2.21 & 2.18 & $(422)$ \\
\hline 4 & 2.13 & 2.09 & $(0 \overline{1} 1)$ & 4 & 3.81 & 3.77 & $(0 \overline{2} 2)$ \\
\hline$\varphi_{1 / 2}$ & $60^{\circ}$ & $\varphi_{110 / 101}$ & $60^{\circ}$ & $\varphi_{1 / 2}$ & $60^{\circ}$ & $\varphi_{220 / 202}$ & $60^{\circ}$ \\
\hline
\end{tabular}

Table 3: Solution of diffraction patterns of the austenite and secondary phase (Fig. 10)

\begin{tabular}{|c|c|c|c|c|c|c|c|}
\hline \multicolumn{4}{|c|}{ White motive } & \multicolumn{4}{c|}{ Blue motive } \\
\hline \multicolumn{2}{|c|}{$\begin{array}{c}\text { Diffraction } \\
\text { pattern }\end{array}$} & \multicolumn{2}{c|}{$\begin{array}{c}\text { Table values of } \\
\text { austenite }\end{array}$} & \multicolumn{2}{c|}{ Diffraction pattern } & \multicolumn{2}{c|}{$\begin{array}{c}\text { Table values of } \\
\mathbf{M}_{23}(\mathbf{C , B})_{6} \text { borocarbide }\end{array}$} \\
\hline No. & $\begin{array}{c}\mathrm{d}_{\mathrm{hk}} \\
\left(\cdot 10^{-10} \mathrm{~m}\right)\end{array}$ & $\begin{array}{c}\mathrm{d}_{\mathrm{hkl}} \\
\left(\cdot 10^{-10} \mathrm{~m}\right)\end{array}$ & $(\mathrm{h} \mathrm{k} 1)$ & No. & $\begin{array}{c}\mathrm{d}_{\mathrm{hkl}} \\
\left(\cdot 10^{-10} \mathrm{~m}\right)\end{array}$ & $\begin{array}{c}\mathrm{d}_{\mathrm{hk}} \\
\left(\cdot 10^{-10} \mathrm{~m}\right)\end{array}$ & $(\mathrm{h} \mathrm{k} 1)$ \\
\hline 1 & 2.06 & 2.09 & $(1 \overline{1} 1)$ & 1 & 5.18 & 5.33 & $(002)$ \\
\hline 2 & 0.83 & 0.83 & $(331)$ & 2 & 2.11 & 2.05 & $(511)$ \\
\hline 3 & 0.75 & 0.74 & $(422)$ & 3 & 1.80 & 1.80 & $(513)$ \\
\hline 4 & 0.81 & 0.81 & $(\overline{24} 0)$ & 4 & 2.12 & 2.05 & $(51 \overline{1})$ \\
\hline$\varphi_{1 / 2}$ & $84^{\circ}$ & $\varphi_{1-11 / 331}$ & $82.4^{\circ}$ & $\varphi_{1 / 2}$ & $77^{\circ}$ & $\varphi_{002 / 511}$ & $78.9^{\circ}$ \\
\hline
\end{tabular}




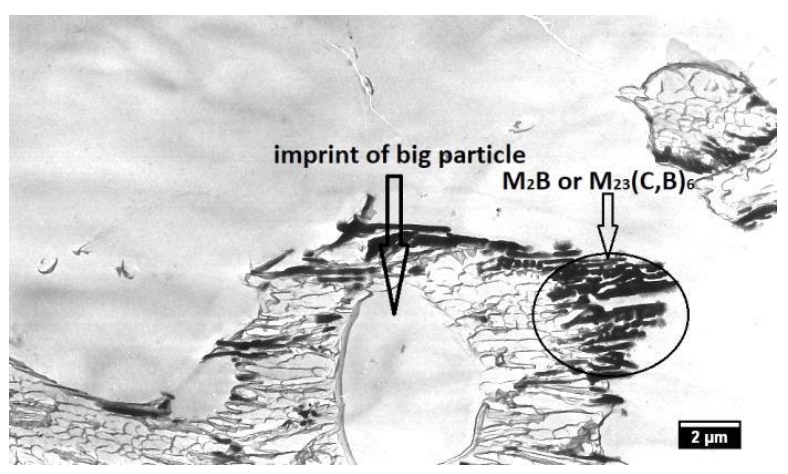

Fig. 11 A detail of lamellar region near the big particle in HAZ (TEM-replica)

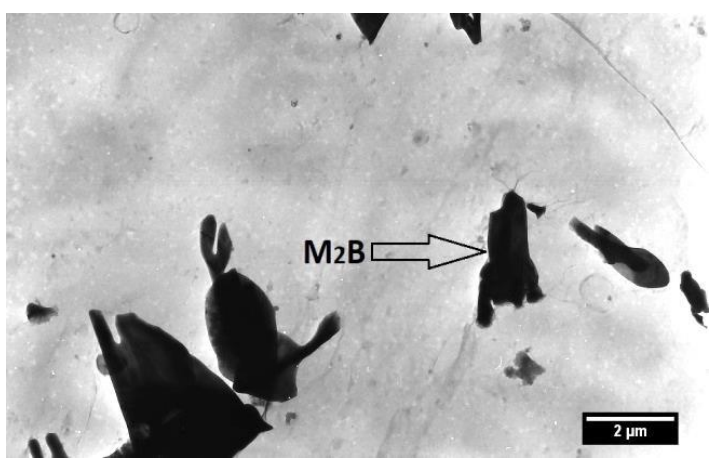

Fig. 12 A detail of the particles at the austenitic grain boundaries in HAZ (TEM-replica)

The microstructure of BM observed by TEM is shown in Figs.13 and 14. The matrix consists of polyhedral austenite with the heterogeneity of grains size. The grain boundaries are pure without secondary phases. Big particles of irregular shape were observed in the austenitic matrix (Fig.13). Size of the particles was in the range from 5 to $20 \mu \mathrm{m}$. The particles were identified by electron diffraction as $\mathrm{M}_{2} \mathrm{~B}$ boride.

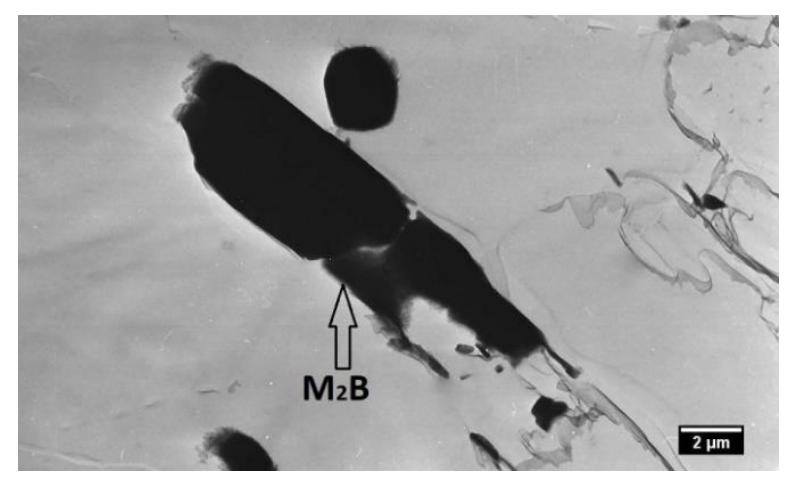

Fig. 13 A detail of extracted big particles in $B M$ (TEM-replica)

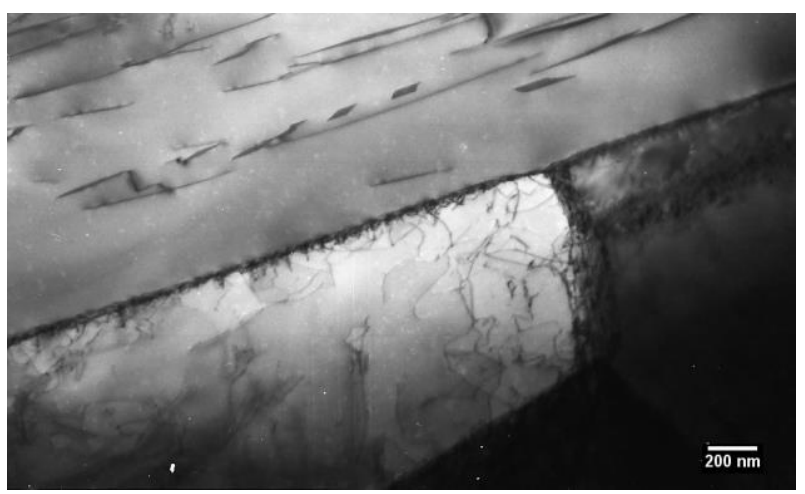

Fig. 14 A detail of austenitic grain boundary in $B M$; the presence of dislocations and stacking faults is typical for austenitic matrix (TEM-thin foil)

The results of EDX analysis TEM analysis supplemented by the selected area electron diffraction confirmed the presence two secondary phases: borocarbide $\mathrm{M}_{23}(\mathrm{C}, \mathrm{B})_{6}$ and boride $\mathrm{M}_{2} \mathrm{~B}$. Therefore the precipitation of secondary phases was very intensive in the weld metal and the heat affected zone, the experimental methods were extended by the energy-dispersive Xray spectroscopy, which was used for the microchemical analyses of the extracted particles in the replicas. Figs. 15 and 16 show the characteristic EDX spectrum of two main precipitated phases. The results of EDX were very similar in the case of all analysed samples. The Fig.17 and Table 4 show the typical results of the EDX analysis.

The particles of the chemical composition: $54.9 \pm 1.4 \mathrm{wt} . \% \mathrm{Cr}, 44.0 \pm 1.4 \mathrm{wt} . \% \mathrm{Fe}$ a $1.1 \pm$ 0.2 wt. $\%$ Ni were observed in WM and HAZ. The particles with chemical composition: 18.7 wt.\% Cr, 69.5 wt. \% Fe a $11.8 \mathrm{wt} . \%$ Ni were analysed in HAZ randomly. In the austenitic matrix the particles with the chemical composition $65.3 \pm 1.5$ wt. $\%$ Cr, $33.9 \pm 1.3$ wt. $\%$ Fe a $0.8 \pm 0.1$ wt.\% Ni were observed in BM. 


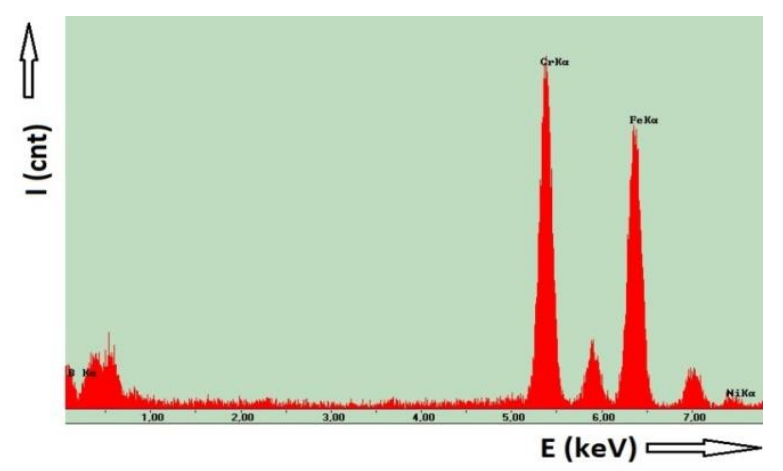

Fig. 15 Characteristic EDX
spectrum of
supposed borocarbide $M_{23}(C, B)_{6}: 51.1 \mathrm{wt} . \% \mathrm{Cr}$, 47.9 wt. \% Fe, $1.0 \mathrm{wt} . \% \mathrm{Ni}$

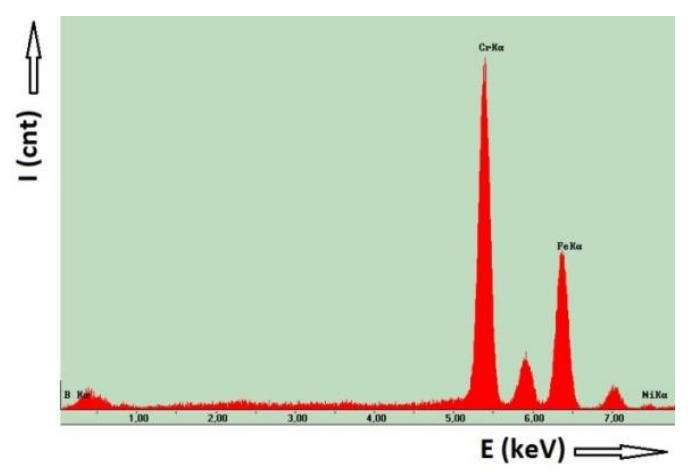

Fig.16 Characteristic EDX spectrum of supposed boride $\mathrm{M}_{2} \mathrm{~B}: 65.6 \mathrm{wt} . \% \mathrm{Cr}, 33.4 \mathrm{wt} . \% \mathrm{Fe}, 1.1$ $w t . \% \mathrm{Ni}$

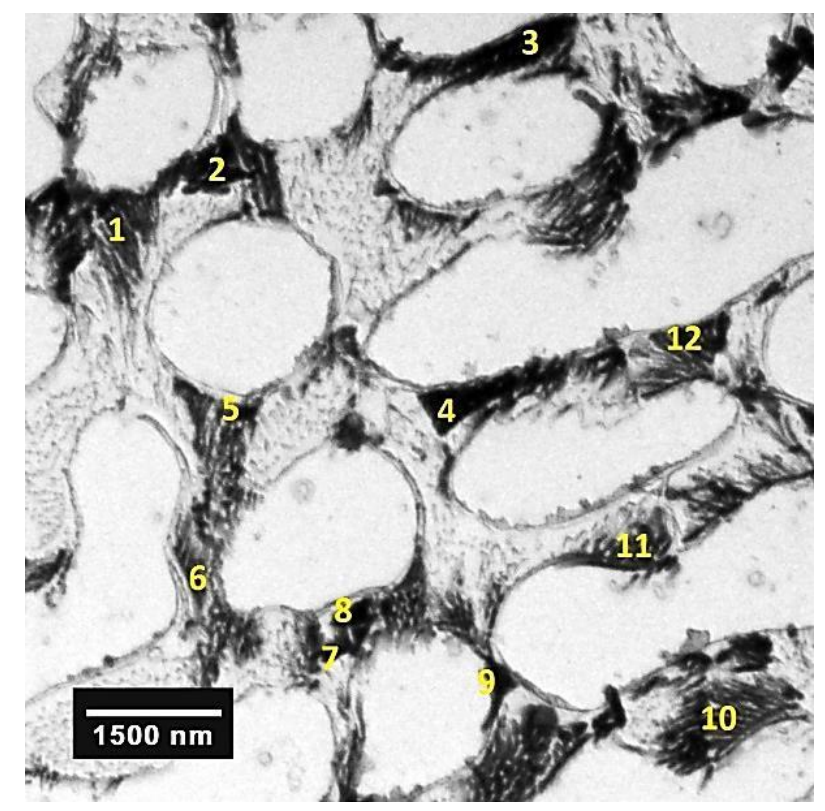

Fig. 17 Extracted particles from eutectics regions in WM; chemical composition of the metal elements of individual particles is summarised in Table 4 (sample 3d, TEM - replica)

\begin{tabular}{|c|c|c|c|}
\hline \multicolumn{4}{|c|}{ Table 4: Chemical composition of the metal } \\
components of the particles in Fig. 16 \\
\hline \multirow{2}{*}{ No. } & \multicolumn{2}{|c|}{ Chemical composition (wt. \%) } \\
\cline { 2 - 4 } & $\mathbf{C r}$ & Fe & Ni \\
\hline $\mathbf{1}$ & 53.9 & 44.1 & 2.0 \\
\hline $\mathbf{2}$ & 51.4 & 46.4 & 2.2 \\
\hline $\mathbf{3}$ & 51.2 & 45.4 & 3.4 \\
\hline $\mathbf{4}$ & 65.6 & 34.4 & - \\
\hline $\mathbf{5}$ & 54.9 & 43.8 & 1.3 \\
\hline $\mathbf{6}$ & 52.5 & 44.6 & 2.9 \\
\hline $\mathbf{7}$ & 51.0 & 46.7 & 2.3 \\
\hline $\mathbf{8}$ & 52.7 & 44.7 & 2.6 \\
\hline $\mathbf{9}$ & 53.7 & 44.5 & 1.8 \\
\hline $\mathbf{1 0}$ & 54.8 & 42.8 & 2.4 \\
\hline $\mathbf{1 1}$ & 54.3 & 44.1 & 1.6 \\
\hline $\mathbf{1 2}$ & 51.0 & 45.8 & 3.2 \\
\hline
\end{tabular}




\section{CONCLUSIONS}

The following results may be drawn from the present study:

1. The microstructure of WM exhibited dendritic morphology. The austenitic dendrites were surrounded by eutectics. The maximum of dendrite regions was observed in the case of the sample $2 \mathrm{~d}$ (around $60 \%$ ). The eutectics was formed by the mixture of the following phases: $\mathrm{M}_{2}(\mathrm{C}, \mathrm{B})$ and $\mathrm{M}_{23}(\mathrm{C}, \mathrm{B})$ borocarbides, $\delta$-ferrite and austenite.

2. HAZs were relatively narrow in the case of all observed samples. The width of HAZ was in the range from 20 to $50 \mu \mathrm{m}$. Microstructure of the HAZ consisted of austenitic matrix and lamellar regions, which were the results of discontinuous precipitation of the $\mathrm{M}_{2}(\mathrm{C}, \mathrm{B})$ and $\mathrm{M}_{23}(\mathrm{C}, \mathrm{B})$ borocarbides. Precipitation of the secondary phases was observed at the austenitic grain boundaries, too.

3. Microstructure of BM was very similar in the case of all analysed samples. The microstructure of $\mathrm{BM}$ consisted of polyhedral austenitic grains and big particles of $\mathrm{M}_{2} \mathrm{~B}$ boride.

\section{Acknowledgements}

The authors wish to thank the financial support of APVV, the Scientific Grant Agency of the Slovak Republic under grant No. APVV-15-0337 "Research on welding of progressive light alloys by beam welding methods" and the project implementation: CE for development and application of advanced diagnostic methods in processing of metallic and non-metallic materials - APRODIMET, ITMS: 26220120048 supported by the Research \& Development Operational Programme funded by the ERDF.

\section{References:}

1. L.M. RONCERY, S.WEBER, W. THEISEN. 2011. Nucleation and precipitation kinetics of $\mathrm{M}_{23} \mathrm{C}_{6}$ and $\mathrm{M}_{2} \mathrm{~N}$ in an Fe-Mn-Cr-C-N austenitic matrix and their relationship with the sensitization phenomenon. Acta Materialia, 59, pp. 6275-6286.

2. H.B. LI, Z.H. JIANG, H. FENG, Q.F. MA, D.P. ZHAN. 2012. Aging precipitation behaviour of $18 \mathrm{Cr}-16 \mathrm{Mn}-2 \mathrm{Mo}-1,1 \mathrm{~N}$ high nitrogen austenitic stainless steel and its influences on mechanical properties. Journal of Iron and Steel Research, International, 19, pp. 43-51.

3. K.K. LO, C.H. SHEK, J.K.L LAI. 2009. Recent developments in stainless steels. In: Materials Science and Engineering: $R$ - Reports, 65, pp. 39-104.

4. H.G. FU, Z.H. LI, Y.P. LEI, Z.Q. JIANG, J.D. XING. 2009. Structural variations in heat treated B-bearing stainless steel. In: Materials and Design, 30, pp. 885-891.

5. B. SHANMUGARAJAN, J.N. CHARY, G. PADMANABHAM, B. ARIVAZHAGAN, K.A. SHAJU, A.K. BHADURI. 2013. Studies on autogenous laser welding of type 304B4 borated stainless steel. In: Optics and Laser in Enginering, 51, pp. 1272-1277.

6. M. DIVYA, S.K. ALBERT. 2018 Dilution effects on weld metal microstructure and liquation cracking susceptibility of 304B4 SS joined E 309 electrode. Journal of Manufacturing Processes, 34, pp. 540-554.

7. M. DOMÁNKOVÁ, K. BÁRTOVÁ, PASTIER, P. 2017. Aging precipitation behaviour of Cr-Mn-N austenitic stainless steels. Materials Science Forum, 891, pp. 155-160. 